\title{
SIKAP DAN KEPUASAN KONSUMEN TERHADAP PRODUK TEMPE BERMEREK DAN TEMPE TANPA MEREK DI BANDAR LAMPUNG
}

\author{
(Attitude and Consumers Satisfaction of Branded and Unbranded Tempeh in Bandar Lampung)
}

Ivo Revita, Teguh Endaryanto, Indah Nurmayasari

Jurusan Agribisnis, Fakultas Pertanian, Universitas Lampung, Jl. Prof. Dr. Soemantri Brojonegoro No. 1

Bandar Lampung 35145, e-mail : teguh.endaryanto@fp.unila.ac.id

\begin{abstract}
This study aims to determine the consumer characteristics, consumer attitudes, and consumer satisfaction of branded and unbranded tempeh in Bandar Lampung. The research is conducted at Pasir Gintung Market. The research samples are 78 people chosen by nonprobability sampling. The data is analyzed by descriptive qualitative, The Multi-attribute Fishbein Models, Customer Satisfaction Index and Importance Performance Analysis. The results showed that the branded and unbranded tempeh consumers were mostly housewives aged 36-50 years old with family income ranging from Rp3,500,000.00-5,000,000.00/month. More than 50 percent consumers were Javanese living in distance of 0-3 $\mathrm{km}$ from the market and bought tempeh in the morning. The results showed that consumer gave the highest attitude scored to the cleanliness attribute of branded tempeh and the taste attribute of unbranded tempeh. The level of consumer satisfaction of branded tempeh and unbranded tempeh were 79.39 percent and 80.47 percent included to the satisfied categories. The performance of product attributes of branded tempeh has beed in accordance with the wishes of consumers. Whereas, the attributes of product cleanliness and product purity of the unbranded tempeh was needed to be improved.
\end{abstract}

Key words: attitude, consumers, satisfaction, tempeh

\section{PENDAHULUAN}

Terjadinya peningkatan jumlah penduduk di Indonesia berdampak pada peningkatan jumlah konsumsi pangan. Konsumsi pangan hendaknya memperhatikan gizi yang cukup dan seimbang sesuai dengan kebutuhan. Salah satu golongan zat gizi yang diperlukan oleh tubuh yaitu protein. Kedelai adalah salah satu tanaman polongpolongan yang merupakan sumber utama protein nabati dan minyak nabati. Dibandingkan protein hewani, protein asal kedelai murah dan terjangkau oleh masyarakat Indonesia. Sebagian besar kedelai oleh masyarakat Indonesia dikonsumsi dalam bentuk produk olahan, seperti tahu, tempe, tauco, oncom, kecap, dan susu kedelai.

Tempe masih menjadi makanan kegemaran masyarakat Indonesia. Hal ini dibuktikan dengan konsumsi tempe masyarakat Indonesia pada periode 2012-2015 melebihi tahu yakni sebesar $7,48 \mathrm{~kg} / \mathrm{kapita} /$ tahun, sedangkan tahu hanya 7,26 kg/kapita/tahun (Pusdatin 2016). Dengan tingginya konsumsi tempe maka semakin banyak pula industri rumah tangga yang memproduksi tempe. Kota Bandar Lampung adalah salah satu daerah yang memiliki banyak agroindustri tempe. Jumlah pengrajin tempe di Bandar Lampung mencapai 302 pengrajin tempe (Dinas Koperasi dan Perdagangan Provinsi Lampung 2012). Industri tempe di Bandar Lampung sebagian besar merupakan industri rumah tangga dengan pengawasan mutu yang tidak maksimal. Hasil survei penelitian yang dilakukan oleh (Istiyanto 2011) terhadap produk tempe di salah satu unit produksi tempe di Kelurahan Gunung Sulah, Bandar Lampung, menunjukkan bahwa produk tempe di tempat tersebut memiliki kadar air 67,479 persen, yang artinya tidak memenuhi syarat mutu yang dikeluarkan oleh Badan Standarisasi Nasional. Kadar air pada produk tempe seharusnya tidak boleh melebihi 65 persen (Badan Standarisasi Nasional 2015).

Produk tempe yang ada di pasaran umumnya belum memiliki merek namun terdapat pula tempe yang telah memiliki merek dagang sehingga konsumen dihadapkan dengan pilihan dalam membeli tempe. Merek tempe yang cukup banyak dijual di Bandar Lampung yaitu tempe dengan merek dagang Tempe Asli H.B dan Tempe Azaki. Kedua merek tempe tersebut telah memiliki izin dari dinas kesehatan dan menggunakan alat yang modern dalam proses produksinya sehingga kedua merek produk tempe tersebut diduga lebih higienis. Merek dagang merupakan salah satu stimulus yang 
dilakukan oleh pemasar yang disampaikan kepada konsumen.

Dalam melakukan pembelian tempe bermerek dan tempe tanpa merek konsumen memiliki sikap dan pertimbangan-pertimbangan tertentu untuk mengambil keputusan. Sikap konsumen yang positif atau negatif akan berpengaruh terhadap keputusan pembelian suatu produk. Setelah konsumen membuat keputusan, konsumen tidak hanya sampai pada proses konsumsi. Konsumen akan melakukan evaluasi terhadap produk atau merek tertentu. Hasil evaluasi ini adalah konsumen puas atau tidak puas terhadap produk atau merek yang telah di konsumsinya. Berdasarkan uraian tersebut, maka tujuan penelitian ini yaitu untuk mengetahui karakteristik, sikap dan kepuasan konsumen tempe bermerek dan tempe tanpa merek di Bandar Lampung.

\section{METODE PENELITIAN}

Penelitian ini menggunakan metode survei. Pengumpulan data dilakukan pada bulan Juli 2018. Penelitian dilaksanakan di salah satu pasar tradisional di Kota Bandar Lampung, yaitu Pasar Pasir Gintung. Penentuan lokasi penelitian dilakukan secara sengaja (purposive) dengan pertimbangan bahwa Pasar Pasir Gintung beroperasi dari pagi sampai sore sehingga responden akan mudah dijumpai. Penjual tempe di Pasar Pasir Gintung saling berdekatan dan menjual tempe bermerek dan tidak bermerek sehingga konsumen memiliki pilihan dalam membeli tempe.

Teknik penarikan sampel dalam penelitian ini menggunakan non probability sampling yaitu dengan metode accidental sampling. Responden dari penelitian ini yaitu konsumen rumah tangga yang ditemui secara kebetulan di lokasi penelitian yang sedang membeli tempe di pedagang yang menjual tempe lebih dari satu jenis varian dan bukan untuk pertama kalinya membeli di pasar tradisional serta merupakan pengambil keputusan pembelian.

Pedagang tempe di Pasar Pasir Gintung yang menjual lebih dari satu jenis varian tempe berjumlah tiga pedagang, yaitu pedagang yang menjual tempe bermerek dan tempe tanpa merek dengan kemasan plastik dan daun. Jumlah populasi konsumen tempe didapat dari hasil pra survei yakni dilihat dari banyaknya konsumen tempe dalam sehari yang membeli di tiga pedagang terpilih. Jumlah populasi di tiga pedagang tempe terpilih yaitu 55 konsumen tempe bermerek dan
104 konsumen tempe tanpa merek. Penentuan jumlah sampel dilakukan dengan menggunakan rumus pengambilan sampel yang mengacu pada teori Issac dan Michael dalam Sugiarto et al. (2003) sebagai berikut.

$\mathrm{n}=\frac{\mathrm{N} Z^{2} \mathrm{~S}^{2}}{\mathrm{Nd}^{2}+\mathrm{Z}^{2} \mathrm{~S}^{2}}$

$$
\begin{aligned}
& \text { Keterangan: } \\
& \mathrm{n} \quad=\text { Jumlah Sampel } \\
& \mathrm{N}=\text { Jumlah populasi } \\
& \mathrm{Z} \quad=\text { Derajat Kepercayaan }(95 \%=1,96) \\
& \mathrm{S}^{2}=\text { Variasi sampel }(5 \%=0,05) \\
& \mathrm{d} \quad=\text { Simpangan baku }(5 \%=0,05)
\end{aligned}
$$

Berdasarkan pada perhitungan dengan rumus tersebut maka jumlah sampel pada penelitian ini adalah 78 orang dimana 33 responden tempe bermerek dan 45 responden tempe tanpa merek. Pengumpulan data penelitian dilakukan pada bulan Juli 2018.

Kuesioner penelitian lebih dulu diuji menggunakan uji validitas dan reliabilitas. Menurut Sufren dan Natanael (2013), kuesioner dikatakan valid, apabila nilai Corrected Item-Total Correlation bernilai di atas 0,2. Uji reliabilitas dengan Cronbach's Alpha dalam kuesioner dapat dikatakan reliabel jika nilai Cronbach Alpha lebih besar dari 0,6 (Ghozali, 2009). Pengolahan data menggunakan Microsoft Office Excel 2010 dan Statistical Product and Service Solutions (SPSS 20).

Uji validitas dan reliabilitas atribut-atribut dalam kuesioner dilakukan terhadap 30 responden pertama sebagai sampel. Hasil uji validitas kuesioner tingkat kepentingan, tingkat kepercayaan, dan tingkat kinerja produk tempe bermerek dan tanpa merek semuanya valid. Nilai Corrected Item-Total Correlation masing-masing atribut menunjukkan angka lebih dari 0,20 yang artinya pertanyaan yang diajukan pada kuesioner adalah valid. Pada uji reliabilitas, nilai Cronbach's Alpha tingkat kepentingan produk tempe sebesar 0,85 dan Cronbach's Alpha tingkat kepercayaan tempe bermerek dan tanpa merek masing-masing 0,78 dan 0,76 maka semua pertanyaan yang diajukan di dalam kuesioner juga dinyatakan reliabel karena nilainya di atas 0,60 .

Tujuan pertama mengenai karakteristik konsumen tempe bermerek dan tempe tanpa merek dianalisis menggunakan analisis deskriptif. Karakteristik konsumen dilihat dari usia responden, pendapatan 
rumah tangga, pendidikan responden, jumlah anggota rumah tangga, pekerjaan responden, jarak tempuh, waktu pembelian, dan etnis.

Tujuan ke dua mengenai sikap konsumen terhadap produk tempe bermerek dan tanpa merek digunakan analisis Multiatribut Fishbein. Formulasi Fishbein merupakan model multiatribut yang paling terkenal. Secara simbolis, rumus tersebut dapat diekspresikan sebagai:

$$
\text { Ao }=\sum_{\mathrm{i}=1}^{\mathrm{n}} \mathrm{b}_{\mathrm{i}} \mathrm{e}_{\mathrm{i}}
$$

Keterangan:

Ao $=$ Sikap terhadap objek

$b_{i}=$ Kekuatan kepercayaan bahwa objek memiliki atribut $\mathrm{i}$

$\mathrm{e}_{\mathrm{i}}=$ Evaluasi mengenai atribut $\mathrm{i}$

$\mathrm{n}=$ Jumlah atribut yang menonjol

Penilaian sikap (Ao) merupakan perkalian antara skor evaluasi (ei) dan skor kepercayaan (bi). Komponen ei dan bi menggambarkan evaluasi atribut-atribut yang terdapat pada tempe yang diukur dengan skor (5), (4), (3), (2), (1).

Tujuan ke tiga mengenai tingkat kepuasan konsumen tempe bermerek dan tempe tanpa merek menggunakan analisis Customer Satisfaction Index (CSI) dan Importance Performance Analysis (IPA). Analisis CSI digunakan untuk mengukur indeks kepuasan konsumen secara keseluruhan dari tingkat kepentingan dan tingkat kinerja yang berguna untuk pengembangan program pemasaran yang dapat mempengaruhi kepuasan pelanggan (Supranto 2006).

Pengukuran CSI terdiri dari empat tahap yaitu:

1. Menghitung Weighting Factor (WF), yaitu mengubah nilai rata-rata kepentingan menjadi angka persentase dari total rata-rata tingkat kepentingan seluruh atribut yang diuji.

2. Menghitung Weighted Score (WS), yaitu menilai perkalian antara nilai rata-rata tingkat kinerja masing-masing atribut dengan Weighting Factor (WF) masing-masing atribut.

3. Menghitung Weighted Total (WT), yaitu menjumlahkan WS dari semua atribut.

4. Menghitung Satisfaction Index, yaitu WT dibagi skala maksimum yang digunakan, dalam penelitian ini skala maksimum yang digunakan adalah 5 kemudian dikalikan $100 \%$.
Tingkat kepuasan responden secara keseluruhan dapat dilihat dari kriteria tingkat kepuasan pelanggan yaitu sangat tidak puas (0-20), tidak puas (21-40), cukup puas (41-60), puas (61-80), dan sangat puas (81-100).

Analisis IPA digunakan untuk menggambarkan kinerja (performance) dibandingkan dengan tingkat kepentingan (importance) menurut yang dipersepsikan oleh konsumen dalam bentuk grafik (Supranto 2006). Hasil analisis IPA digambarkan pada diagram kartesius yang terdiri dari empat kuadran. Kuadran I (Prioritas Utama), Kuadran II (Pertahankan Prestasi), Kuadran III (Prioritas Rendah), dan Kuadran IV (Berlebihan).

\section{HASIL DAN PEMBAHASAN}

\section{Karakteristik Konsumen Tempe Bermerek dan Tanpa Merek}

Sebagian besar konsumen yang membeli tempe bermerek dan tanpa merek berada pada usia 36-50 tahun dan masuk ke dalam kelompok usia separuh baya dan tergolong masih usia produktif untuk melakukan berbagai kegiatan atau pekerjaan. Jumlah anggota keluarga konsumen terdiri dari 2-5 orang dengan pendapatan rumah tangga sebesar Rp3.500.000,00-5.000.000,00. Jarak pembelian 0$3 \mathrm{~km}$ dan membeli pada pagi hari. Sebagian besar pekerjaan konsumen adalah ibu rumah tangga dengan jenjang pendidikan terakhir yaitu SMA serta lebih dari 50 persen bersuku Jawa. Hal ini sejalan dengan hasil penelitian Prasetyo (2018) tentang kepuasan dan faktor yang mempengaruhi permintaan tempe di Bandar Lampung yang menyatakan konsumen tempe di Bandar Lampung adalah ibu rumah tangga berpendidikan terakhir SMA serta bersuku Jawa.

\section{Sikap Konsumen Tempe Bermerek dan Tempe Tanpa Merek}

Sikap konsumen terhadap tempe bermerek dan tanpa merek merupakan ungkapan perasaan seseorang terhadap produk tempe bermerek dan tanpa merek apakah disukai atau tidak. Atributatribut produk yang diidentifikasi pada penelitian ini adalah rasa tempe, aroma tempe, harga tempe, tekstur tempe, kondisi kemasan, warna tempe, kebersihan produk, kemurnian produk, kemudahan memperoleh, dan standarisasi produk. 
Tabel 1. Hasil analisis sikap responden terhadap produk tempe bermerek dan tanpa merek

\begin{tabular}{lccccc}
\hline Atribut & Tempe & \multicolumn{2}{c}{ Tempe Bermerek } & \multicolumn{2}{c}{ Tempe Tanpa Merek } \\
\hline & ei & bi & ei x bi & bi & ei x bi \\
\hline - Rasa & 4,50 & 3,97 & 17,86 & 4,13 & 18,60 \\
- Aroma & 3,97 & 4,24 & 16,86 & 4,04 & 16,07 \\
- Harga & 3,76 & 3,27 & 12,29 & 4,29 & 16,11 \\
- Tekstur & 3,73 & 3,88 & 14,47 & 3,71 & 13,85 \\
- Kondisi Kemasan & 3,95 & 3,85 & 15,20 & 4,20 & 16,58 \\
- Warna & 3,94 & 4,21 & 16,58 & 4,29 & 16,88 \\
- Kebersihan & 4,64 & 4,33 & 20,11 & 3,76 & 17,43 \\
- Kemurnian & 4,51 & 4,24 & 19,15 & 3,78 & 17,05 \\
- Kemudahan Memperoleh & 3,87 & 3,48 & 13,49 & 4,58 & 17,72 \\
$\bullet$ Standarisasi & 3,79 & 4,06 & 15,41 & 3,51 & 13,32 \\
\hline Total & & & 161,42 & & 163,62 \\
\hline
\end{tabular}

Dari hasil perhitungan analisis sikap responden yang diperoleh, dapat dilihat pada Tabel 1 bahwa skor evaluasi kepentingan (ei) atribut kebersihan produk tempe memperoleh skor tertinggi yaitu 4,64. Hal itu menunjukkan bahwa atribut kebersihan produk merupakan atribut yang paling diinginkan responden dibandingkan dengan atribut tempe lainnya. Responden menginginkan tempe yang bersih yakni tempe yang tidak ada benda asing lain di dalamnya seperti kerikil-kerikil kecil, potongan lidi dan lain-lain. Selain kebersihan produk, atribut lain yang dipentingkan konsumen tempe yaitu atribut kemurnian produk dan rasa tempe.

Skor kepercayaan (bi) tertinggi pada tempe bermerek yaitu atribut kebersihan produk dengan skor 4,33 namun skor yang diperoleh masih lebih rendah dari skor evaluasi kepentingan atribut. Hasil penelitian ini sejalan dengan penelitian Anggiasari, Indriani, dan Endaryanto (2016) yang menyatakan bahwa tingkat kepercayaan responden sayuran organik di Bandar Lampung menunjukkan bahwa atribut kebersihan dinilai tertinggi. Atribut kepercayaan terendah pada tempe bermerek adalah harga tempe. Responden mengeluhkan harga tempe yang dinilai lebih mahal daripada tempe tanpa merek.

Berbeda dengan tempe bermerek, atribut skor kepercayaan tertinggi pada tempe tanpa merek adalah atribut kemudahan memperoleh produk. Responden menilai bahwa untuk memperoleh tempe sangat mudah karena banyak sekali pedagang yang menjual tempe, baik di pasar, warung, supermarket, dan pedagang keliling. Atribut skor kepercayaan terendah pada tempe tanpa merek adalah standarisasi produk. Responden beranggapan bahwa standarisasi produk yang ada pada tempe tanpa merek belum jelas karena tidak adanya kejelasan mengenai izin, berbeda dengan tempe bermerek yang telah menuliskan nomor izin dari dinas kesehatan pada kemasannya.

Hasil capaian skor kepercayaan atribut tempe bermerek yang melebihi skor evaluasi kepentingan atribut terdapat empat atribut yaitu aroma, tekstur, warna dan standarisasi produk. Konsumen menilai tekstur tempe bermerek lebih padat dari tempe biasanya, aroma tempe bermerek khas tempe tanpa ada bau amoniak, warna tempe putih merata pada seluruh permukaan, standarisasi produk sangat jelas karena sudah mencantumkan izin dinas kesehatan pada kemasan tempe bermerek.

Pada tempe tanpa merek terdapat lima atribut yang mendapat hasil capaian skor kepercayaan lebih dari skor evaluasi kepentingan yaitu atribut aroma, harga, kondisi kemasan, warna dan kemudahan memperoleh. Aroma tempe tanpa merek menurut konsumen juga khas tempe tanpa ada bau amoniak, warna putih merata pada seluruh permukaan, harga tempe tanpa merek yang lebih murah dari tempe bermerek, kondisi kemasan tempe tanpa merek sudah baik dan bervariasi yaitu terdapat kemasan plastik dan daun pisang, dan kemudahan memperoleh produk tempe yang dinilai konsumen sangat mudah.

Hasil analisis sikap multi atribut responden tempe bermerek dan tempe tanpa merek dapat dilihat pada Tabel 1. Skor sikap (Ao) tempe bermerek didapatkan hasil sebesar 161,42, sedangkan skor sikap tempe tanpa merek didapatkan hasil senilai 163,62 . 
Tabel 2. Hasil perhitungan Customer Satisfaction Index responden tempe bermerek

\begin{tabular}{lcccc}
\hline Atribut & $\begin{array}{c}\text { Rata-rata } \\
\text { skor kepentingan }\end{array}$ & WF & $\begin{array}{c}\text { Rata-rata } \\
\text { skor kinerja }\end{array}$ & WS \\
\hline - Rasa & 4,58 & 0,11 & 3,97 & 0,45 \\
- Aroma & 3,82 & 0,09 & 4,24 & 0,40 \\
- Harga & 4,03 & 0,10 & 3,27 & 0,33 \\
- Tekstur & 3,52 & 0,09 & 3,88 & 0,34 \\
- Kondisi Kemasan & 3,82 & 0,09 & 3,85 & 0,36 \\
- Warna & 3,79 & 0,09 & 4,21 & 0,39 \\
- Kebersihan & 4,76 & 0,12 & 4,33 & 0,51 \\
- Kemurnian & 4,61 & & 4,24 & 0,48 \\
- Kemudahan Memperoleh & 3,79 & 0,09 & 3,48 & 0,33 \\
- Standarisasi & 3,82 & 0,09 & 4,06 & 0,38 \\
\hline WT & 40,52 & & & 3,97 \\
\hline CSI (\%) & \multicolumn{3}{|c}{} \\
\hline
\end{tabular}

Skor sikap pada tempe bermerek sedikit lebih rendah dari tempe tanpa merek di mana pada tempe tanpa merek terdapat lima atribut yang mendapat skor kepercayaan lebih tinggi dari skor evaluasi kepentingan sedangkan pada tempe bermerek hanya empat atribut.

Atribut yang mendapat skor sikap tertinggi pada tempe bermerek dan tanpa merek berbeda. Pada tempe bermerek skor sikap tertinggi adalah atribut kebersihan produk. Pada tempe tanpa merek atribut rasa memperoleh skor sikap tertinggi. Skor sikap terendah pada tempe bermerek adalah atribut harga, sedangkan pada tempe tanpa merek adalah standarisasi produk. Ini menunjukkan adanya keunggulan pada masing-masing produk menurut penilaian konsumen, di mana tidak bisa saling tergantikan sehingga masing-masing tetap memiliki konsumen.

\section{Tingkat Kepuasan Konsumen Tempe Bermerek dan Tanpa Merek}

Analisis tingkat kepuasan konsumen diukur dengan menggunakan Customer Satisfaction Index (CSI) dan Importance Performance Analysis (IPA). CSI atau yang disebut indeks kepuasan konsumen adalah suatu ukuran keterkaitan konsumen kepada suatu merek atau produk. Pengukuran dengan menilai tingkat kepentingan dan tingkat kinerja atribut produk.

Nilai CSI tempe bermerek pada Tabel 2 adalah sebesar 79,33 persen. Berdasarkan hasil perhitungan pada penelitian ini, nilai CSI konsumen tempe bermerek berada pada rentang skala 61-80 persen dan masuk ke dalam kriteria puas. Konsumen tempe bermerek memberikan nilai kepuasan tertinggi pada atribut kebersihan produk. Menurut konsumen tempe bermerek, produk tempe bermerek dinilai bersih dari bendabenda asing seperti serpihan batu, lidi dan benda asing lainnya.

Tabel 3. Hasil perhitungan Customer Satisfaction Index responden tempe tanpa merek

\begin{tabular}{lcccc}
\hline \multicolumn{1}{c}{ Atribut } & $\begin{array}{c}\text { Rata-rata } \\
\text { skor kepentingan }\end{array}$ & WF & $\begin{array}{c}\text { Rata-rata } \\
\text { skor kinerja }\end{array}$ & WS \\
\hline$\bullet$ Rasa & 4,44 & 0,11 & 4,13 & 0,45 \\
- Aroma & 4,09 & 0,10 & 4,04 & 0,41 \\
- Harga & 3,56 & 0,09 & 4,29 & 0,37 \\
- Tekstur & 3,89 & 0,10 & 3,71 & 0,35 \\
- Kondisi Kemasan & 4,04 & 0,10 & 4,20 & 0,42 \\
- Warna & 4,04 & 0,10 & 4,29 & 0,43 \\
- Kebersihan & 4,56 & 0,11 & 3,76 & 0,42 \\
- Kemurnian & 4,44 & 0,11 & 3,78 & 0,41 \\
- Kemudahan Memperoleh & 3,93 & 0,10 & 4,58 & 0,44 \\
$\bullet$ Standarisasi & 3,78 & 0,09 & 3,51 & 0,33 \\
\hline WT & 40,78 & & & 4,02 \\
\hline CSI $(\%)$ & & & \\
\hline
\end{tabular}


Konsumen tempe bermerek memberikan nilai kepuasan terendah pada atribut harga tempe. Responden mengeluhkan harga tempe yang dinilai lebih mahal daripada tempe tanpa merek.

Hasil perhitungan CSI responden tempe tanpa merek dapat dilihat pada Tabel 3. Nilai CSI yang diperoleh responden tempe tanpa merek yaitu 80,48. Berdasarkan hasil perhitungan CSI, penilaian yang dilakukan konsumen masuk dalam kriteria puas dan berada pada rentang skala 61-80 persen. Pada perhitungan tingkat kepuasan tempe tanpa merek, konsumen memberikan nilai kepuasan tertinggi pada rasa.

Penilaian kepuasan konsumen pada kinerja produk tempe bermerek terdapat lima atribut yang mendapatkan skor melebihi capaian skor evaluasi kepentingan, sedangkan pada tempe tanpa merek terdapat empat atribut. Pada tingkat kepuasan konsumen, baik tempe bermerek dan tempe tanpa merek sama-sama memberi kepuasan konsumen terhadap kinerja produk yang diberikan. Hasil perhitungan CSI pada tempe bermerek dan tanpa merek masuk ke dalam kriteria puas.

Hal ini tidak jauh berbeda dengan hasil penelitian Pradipta, Indriani dan Soelaiman (2016) yang menyatakan bahwa konsumen merasa puas terhadap tauco dan masuk ke dalam rentang skala 61-80 persen. Pada penelitian tersebut mengenai kepuasan konsumen tauco, konsumen memberikan nilai kepuasan tertinggi pada atribut rasa dan ini sejalan dengan perhitungan tingkat kepuasan konsumen tempe tanpa merek, tetapi berbeda pada tempe bermerek yang nilai kepuasan tertinggi pada atribut kebersihan produk, sedangkan atribut rasa berada pada urutan ke tiga setelah kemurnian produk.

Setelah menghitung tingkat kepuasan konsumen tempe bermerek dan tanpa merek dengan menggunakan metode CSI didapatkan angka yang menyatakan seberapa besar tingkat kepuasan konsumen terhadap produk tersebut. Tingkat kepuasan konsumen dipengaruhi oleh atribut produk yang dianggap penting oleh konsumen.

Dengan menggunakan metode IPA maka dapat diketahui atribut yang mana yang akan menjadi prioritas untuk diperbaiki dan ditingkatkan oleh produsen. Hasil analisis IPA tempe bermerek dan tempe tanpa merek dapat dilihat pada Gambar 1.

\section{Kuadran I Prioritas Utama}

Kuadran pertama memuat atribut-atribut yang dianggap penting oleh konsumen tetapi pada kenyataannya atribut-atribut tersebut belum sesuai dengan harapan konsumen dan pihak produsen belum melaksanakannya dengan baik. Pada produk tempe bermerek tidak ada atribut yang masuk ke dalam kuadran I, artinya produk tempe bermerek sudah melaksanakan kinerja produk sesuai dengan keinginan konsumen. Pada produk tempe tanpa merek terdapat dua atribut yang masuk ke dalam kuadran I yakni atribut kebersihan produk dan kemurnian produk. Kedua atribut ini dianggap sangat penting bagi konsumen tempe namun produsen tempe tanpa merek belum melaksanakan sesuai dengan keinginan konsumen. Pada tempe tanpa merek masih ditemui serpihan batu-batu, lidi, menir jagung, ampas kedelai dan lain sebagainya.

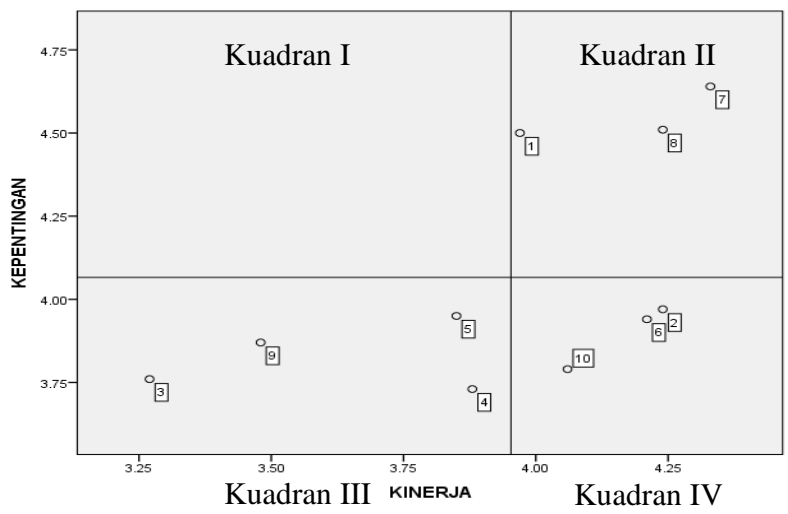

Tempe Bermerek

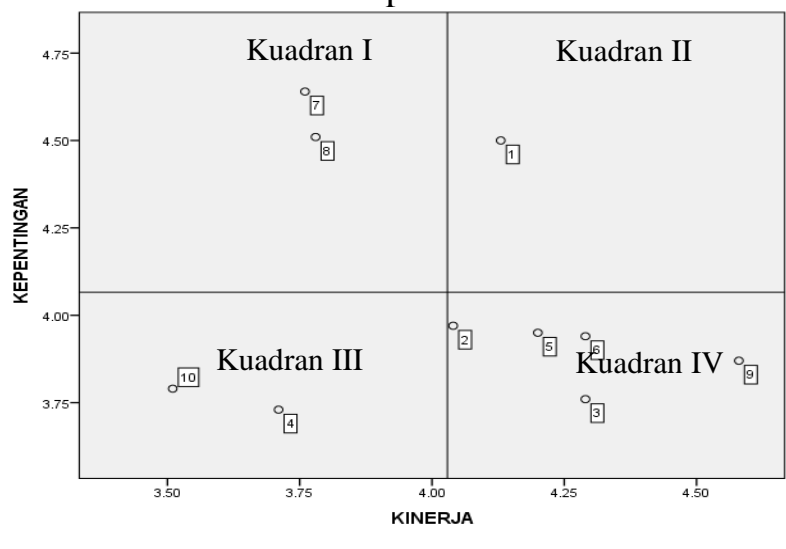

Tempe Tanpa Merek

Gambar 1. Diagram kartesius tempe bermerek dan tempe tanpa merek

\begin{tabular}{|c|c|c|}
\hline \multicolumn{3}{|c|}{ Keterangan : } \\
\hline \\
\hline \multirow{2}{*}{\multicolumn{3}{|c|}{$\begin{array}{l}6: \text { Warna Tempe } \\
7: \text { Kebersihan Produk } \\
8: \text { Kemurnian Produk }\end{array}$}} \\
\hline & & \\
\hline \multicolumn{3}{|r|}{$\begin{array}{l}8: \text { Kemurnian Produk } \\
9: \text { Kemudahan Memperoleh }\end{array}$} \\
\hline & : Kondisi Kemasan & 10 : Standarisasi Produk \\
\hline
\end{tabular}




\section{Kuadran II Pertahankan Prestasi}

Pada kuadran II atribut-atribut ini memiliki tingkat harapan dan kinerja yang tinggi. Hal ini menunjukkan bahwa atribut tersebut penting dan memiliki kinerja yang tinggi dan wajib dipertahankan oleh produsen dan hasilnya yang memuaskan. Pada produk tempe bermerek ada tiga atribut yang termasuk ke dalam kuadran ini yakni atribut rasa, kebersihan produk dan kemurnian produk. Konsumen menilai atribut rasa tempe bermerek sudah cukup baik, beberapa konsumen menilai rasa tempe bermerek enak dan gurih. Pada atribut kebersihan dan kemurnian produk tempe bermerek juga menjadi hal yang penting, kebersihan dan kemurnian tempe bermerek tergolong bersih karena tidak adanya benda asing dan bahan lain selain kedelai dan ragi serta bersih dari batu-batu kecil, menir jagung, ampas kedelai dan sebagainya.

Pada tempe tanpa merek hanya ada satu atribut yang masuk ke dalam kuadran II yaitu rasa tempe. Tingkat kinerja rasa tempe sudah dinilai baik oleh konsumen, rasa tempe tanpa merek menurut konsumen sudah enak dan perlu dipertahankan. Namun masih banyak atribut lain yang perlu ditingkatkan lagi agar kepuasan konsumen tempe tanpa merek meningkat, dilihat hanya ada satu atribut yang masuk ke dalam kuadran ini. Berdasarkan penelitian terdahulu yang dilakukan oleh Bangun, Indriani, Soelaiman (2017) mengenai analisis tingkat kepuasan konsumen Rumah Makan Ayam Penyet Hang Dihi Bandar Lampung menyatakan bahwa atribut rasa terdapat pada kuadran ke II pada diagram kartesius.

\section{Kuadran III Prioritas Rendah}

Atribut-atribut dalam kuadran ini dianggap kurang penting oleh konsumen dan pada kenyataannya kinerjanya juga biasa saja. Atribut produk tempe bermerek yang termasuk ke dalam kuadran ini adalah harga tempe, tekstur tempe, kondisi kemasan, dan kemudahan memperoleh, sedangkan pada tempe tanpa merek yaitu tekstur tempe dan standarisasi produk. Produsen perlu mempertimbangkan kembali atribut yang masuk ke dalam kuadran ini dengan melihat atribut yang mempunyai pengaruh terhadap manfaat yang dirasakan oleh konsumen itu besar atau kecil dan untuk mencegah atribut tersebut bergeser ke kuadran I.

\section{Kuadran IV Berlebihan}

Atribut pada kuadran ini memiliki tingkat harapan rendah menurut konsumen namun memiliki kinerja yang baik oleh produsen, sehingga dianggap berlebihan oleh konsumen. Pada tempe bermerek yang berada dalam kuadran ini adalah aroma, warna dan standarisasi produk. Pada tempe tanpa merek yaitu atribut aroma, harga, kondisi kemasan, warna tempe dan kemudahan memperoleh. Atribut-atribut tersebut mendapatkan skor kinerja melebihi capaian skor evaluasi kepentingan. Hal ini menunjukkan atribut-atribut tersebut yang mempengaruhi kepuasan konsumen dinilai berlebihan dalam pelaksanaannya, dikarenakan konsumen menganggap tidak terlalu penting diharapkan tetapi pelaksanaannya dilakukan baik sekali oleh produsen.

\section{KESIMPULAN}

Karakteristik konsumen pada konsumen tempe bermerek dan tanpa merek berada pada usia 36-50 tahun, sebagian besar ibu rumah tangga dengan jenjang pendidikan terakhir yaitu SMA, jumlah anggota keluarga 2-5 orang dengan pendapatan Rp3.500.0,00-5.000.000,00 dan bersuku Jawa dengan jarak pembelian 0-3 km dan membeli pada pagi hari. Dalam penilaian sikap konsumen, produk tempe tanpa merek mendapatkan nilai lebih tinggi $(163,62)$ dibandingkan tempe bermerek $(161,42)$. Konsumen tempe bermerek dan tanpa merek merasa puas dengan seluruh atribut tempe yang dimiliki dengan nilai CSI pada tempe tanpa merek adalah 80,48 dan tempe bermerek yaitu sebesar 79,33. Pada produk tempe bermerek, produsen sudah melaksanakan kinerja atribut produk sesuai dengan keinginan konsumen dan pada tempe tanpa merek, produsen perlu meningkatkan atribut kebersihan produk dan kemurnian produk.

\section{DAFTAR PUSTAKA}

Anggiasari NM, Indriani $\mathrm{Y}$, dan Endaryanto $\mathrm{T}$. 2016. Sikap dan pengambilan keputusan pembelian sayuran organik oleh konsumen di Kota Bandar Lampung. JIIA, Volume 4 No. 4:391-397. http://jurnal.fp.unila.ac.id/index. php/JIA/article/view/1521. [2 Desember 2017].

Badan Standarisasi Nasional. 2015. Tempe Kedelai. Badan Standarisasi Nasional. Jakarta.

Bangun YF, Indriani Y, dan Soelaiman A. 2017. Sikap dan kepuasan konsumen Rumah Makan Ayam Penyet Hang Dihi di Bandar Lampung . 
JIIA, Volume 5 No. 1, Februari 2017:101-108. http://jurnal.fp.unila.ac.id/index.php/JIA/articl e/download/1680/1506. [6 Desember 2017].

Dinas Koperasi dan Perdagangan Provinsi Lampung. 2012. Jumlah Industri Rumah Tangga Tempe di Provinsi Lampung. Lampung.

Ghozali I. 2009. Aplikasi Analisis Multivariate dengan Program SPSS. Edisi Ke-4. Universitas Diponegoro. Semarang.

Istiyanto R. 2011. Penyusunan Draft Standard Operating Procedure (SOP) Pengolahan Tempe (Studi Kasus Di Salah Satu Industri Pengolahan Tempe Gunung Sulah Bandar Lampung). Skripsi. Fakultas Pertanian. Universitas Lampung. Bandar Lampung.

Pradipta R, Indriani Y, dan Soelaiman A. 2016. Tingkat kepuasan dan loyalitas konsumen tauco di Kota Prabumulih. JIIA, Vol. 4 No. 1, Januari 2016:86-93. http://jurnal.fp.unila.ac.
id/index.php/JIA/article/download/1218/1115. [27 Januari 2018].

Prasetyo RE. 2018. Analisis Kepuasan dan FaktorFaktor yang Mempengaruhi Permintaan Tempe Oleh Konsumen Rumah Tangga di Kota Bandar Lampung. Skripsi. Fakultas Pertanian. Universitas Lampung. Bandar Lampung.

Pusdatin [Pusat Data dan Sistem Informasi Pertanian]. 2016. Buletin Triwulanan Konsumsi Pangan Vol. 7 No. 1 Tahun 2016. Kementerian Pertanian. Jakarta.

Sufren dan Natanael Y. 2013. Mahir Menggunakan SPSS Secara Otodidak. Elex Media. Jakarta.

Sugiarto, Siagian D, Sunaryanto LT, dan Oetomo DS. 2003. Teknik Sampling. Gramedia Pustaka Utama. Jakarta.

Supranto J. 2006. Pengukuran Tingkat Kepuasan Pelanggan untuk Meningkatkan Pangsa Pasar. Rineka Cipta. Jakarta. 